\title{
SERUM CONCENTRATION OF IMMUNE, ENDOCRINE AND ENDOTHELIAL BIOMARKERS IN PATIENTS WITH RHEUMATOID ARTHRITIS ASSOCIATED WITH DIFFERENT VARIANTS OF METABOLIC STATUS TREATED WITH INFLIXIMAB
}

Oranskiy S. P., Yeliseyeva L. N.

\section{АИНАМИЧЕСКИЕ ИЗМЕНЕНИЯ СЫВОРОТОЧНОЙ КОНЦЕНТРАЦИИ НЕКОТОРЫХ ИММУНОЭНАОКРИННЫХ И ЭНАОТЕАИААЬНЫХ БИОМАРКЕРОВ ПРИ ОСНОВНЫХ ВАРИАНТАХ МЕТАБОАИЧЕСКИХ НАРУШЕНИЙ У ПАЦИЕНТОВ С РЕВМАТОИАНЫМ АРТРИТОМ НА ФОНЕ ТЕРАПИИ ИНФАИКСИМАБОМ}

\author{
С. П. Оранский, А. Н. Елисеева
}

\section{Кубанский госуАарственный МеАицинский Университет, КрасноАар, Российская ФеАерация}

Aim of the study: Evaluation the effect of infliximab (I) on traditional indicators of activity and several cytokine, hormonal and endothelial serum biomarkers in patients with rheumatoid arthritis (RA) with different types of metabolic status.

Material and Methods. 37 patients with RA (30 women and 7 men) with DAS28 index 7.2-7.4 (associated with normal body mass index - BMI, obesity and cachexia) treated with I and methotrexate were included in this study. In all patients we determined traditional markers of RA activity (DAS28, ESR, C-reactive protein) and serum biomarkers tumour necrosis factor- $\alpha$ (TNF- $\alpha$ ), interleukins-6, 10 (IL-6, IL-10), adiponectin, vascular endothelial growth factor (VEGF), cortisol using enzyme linked immunosorbent assay.

Results. In all patients we found high activity of RA traditional markers and high levels of TNF- $\alpha$, IL- 6 , VEGF before I started. Low initial levels of adiponectin and high levels of cortisol we found in patients with RA associated with obesity. After 22 weeks of I course we determined decreasing of traditional RA markers and TNF- $\alpha$, IL-6, VEGF in patients with normal BMI. In patients with RA and obesity we found increasing of adiponectin concentration from $2.1(0.8-3.9) \mathrm{ng} / \mathrm{ml}$ to $5.8(4.9-7.7) \mathrm{ng} / \mathrm{ml}$, decreasing of high TNF- $\alpha$ initial level and no reduction of high IL-6 initial level.

Conclusions. Thus, we have found that in general, infliximab therapy may be effective in any variants of metabolic status in patients with RA through beneficial effect with correction of most traditional and serum biomarkers. Because obese patients present a more pronounced pro-inflammatory activation and decreased adiponectin effectiveness of the biological therapy may be reduced in this group.

Key words: rheumatoid arthritis, obesity, cytokines, endothelial dysfunction, biomarkers

Цель исследования: оценить влияние инфликсимаба на традиционные показатели активности ревматоидного артрита и ряд патогенетически значимых иммунноэндокринных и эндотелиальных сывороточных биомаркеров при различных вариантах метаболических нарушений у пациентов с ревматоидным артритом (РА).

Материал и методы. 37 пациентов с PA (DAS28 7,2-7,4) при наличии нормального индекса массы тела ИМТ, ожирения и гипотрофии на фоне терапии инфликсимабом были включены в данное исследование. У всех пациентов определены традиционные маркеры активности PA (DAS28, ESR, C-reactive protein), a также следующие сывороточные биомаркеры - фактор некроз опухоли- $\alpha$ (TNF- $\alpha$ ), интерлейкины-6, 10 (IL-6, IL-10), адипонектин, васкулярный эндотелиальный фактор роста (VEGF), кортизол, использовался твердофазный иммуноферментный анализ.

Результаты исследования. У всех пациентов определена исходная высокая активность РА по результатам исследования традиционных маркеров, а также высокие сывороточные уровни TNF- $\alpha$, IL-6, VEGF. Cнижение исходных сывороточных уровней зафиксировано для адипонектина и кортизола в группе РА с ожирением. После 22-недельного курса лечения определено снижение традиционных маркеров активности PA и TNF- $\alpha$, IL-6, VEGF у пациентов с нормальным ИМТ. У пациентов с PA в сочетании с ожирением обнаружено увеличение сывороточной концентрации адипонектина от 2,1 (0,8-3,9) нг/мл до 5,8 $(4,9-7,7)$ нг/мл, снижение TNF- $\alpha$, отсутствие изменений исходно повышенного уровня IL-6.

Выводы. Нами установлено, что инфликсимаб может быть эффективен при любом варианте метаболических изменений на фоне РА с учетом положительного влияния на большинство изучавшихся сывороточных биомаркеров. В то же время эффективность терапии инфликсимабом может снижаться у пациентов с ожирением.

Ключевые слова: ревматоидный артрит, ожирение, цитокины, эндотелиальная дисфункция, биомаркеры 
R heumatoid arthritis (RA) is one of the most frequent autoimmune diseases, with up to $1.3 \%$ prevalence in the world, which is also associated with a high risk of disability [3, 7]. Death frequency in RA higher than in general population and registered at the same level as the under severe cardiovascular disease, diabetes and some tumors [12]. However, little is known about the interactions between different immune, endocrine and endothelial factors in RA patients with different variants of metabolic status that may be associated with poor quality of life and lack of effectiveness of therapy [5].

An inadequate production of sex hormones, cortisol, adrenocorticotropic hormone and cytokines described in RA patients [8], however, its limited data about this factors in different types of metabolic status in RA.

Metabolic changes can be associated with the effects of adipokines. One of the key adipokines is adiponectin, a cytokine-like protein hormone that regulates metabolism and may interacts with cytokines, endothelial growth factors [4, 13]. Adiponectin level decreases in patients with obesity, metabolic syndrome and type II diabetes mellitus that that associates with a poor prognosis [14]. Increased production of serum adiponectin and correlation of adiponectin with proinflammatory cytokines was found in RA patients with normal body weight $[9,11]$. Serum concentration of key pathogenic factors (cortisol, adiponectin, interleukins and endothelial growth factors) in RA patients with different variants of metabolic status has not been investigated completely.

In recent years, biological therapy of rheumatoid arthritis with antibodies to proinflammatory cytokine actively administered. Gremese E. et al. found the decrease in efficiency of anti-cytokine therapy in patients with obesity [6]. Also it is not enough to determine the possible influence of biological therapy in patients with $\mathrm{RA}$ as traditional indicators of RA activity, and the most important immune, endocrine, and endothelial biomarkers at various variants of metabolic status.

Aim of the study was to evaluate the effect of infliximab on traditional indicators of activity and several cytokine, hormonal and endothelial serum biomarkers in patients with rheumatoid arthritis with different types of metabolic status.

Material and Methods. The study was approved by the Ethics Committee of the Human Studies of Kuban State Medical University (Krasnodar, Russian Federation) and was conducted according to principles of the Helsinki Declaration of the World Medical Association (2008 revision). Informed consent was received from all patients and the control group. The study included 37 patients (30 women and 7 men) admitted to the Rheumatology Department of Kuban State Medical University and Krasnodar Regional Hospital with RA. They were divided into 3 groups: patients with normal BMI $(n=15)$, patients with obesity $(n=12)$, and patients with underweight $(n=10)$ according WHO classification [15]. The control group (20 persons) was formed from healthy blood donors and randomized with RA groups using stratified randomization by age and sex. RA groups and the control group did not differ according to demographic characteristics. RA groups did not differ according to clinical characteristics and medications (Table 1).

We excluded the patients with concomitant infectious, oncological diseases, purulent conditions of any localization, and those with renal, hepatic, or cardiac insufficiency. Before enrollment in the study the majority of RA patients received methotrexate as a disease-modifying drug, without differences in dosages and duration of therapy between RA groups. Most patients received low-dose prednisolone for $16.2 \pm 5$ months and NSAIDs in demand mode during 19.2 \pm 6 months before entering the study. In the formation of groups into ac- count information about the equivalence of the total dosage of prednisone and NSAIDs All patients were treated with infliximab (Remicade, Schering-Plough). Dosing and administration maintained by the manufacturer's annotations. A single dose was adjusted at the rate of $3 \mathrm{mg} / \mathrm{kg}$. Infusions were repeated at 2 and 6 weeks after the first infusion and then every 8 weeks (total number of injections ranged from 5 to 12). Patients were assessed standard clinical and immunological markers RA. The RA diagnosis was established by ACR diagnostic criteria (1987) [1] or ACR/EULAR (2010) [2, 10].

Basic demographic and clinical characteristics of the study cohort

\begin{tabular}{|c|c|c|c|c|}
\hline Parameter & $\begin{array}{c}\text { Control } \\
\text { group } \\
(n=20)\end{array}$ & $\begin{array}{c}\text { Normal } \\
\text { BMI } \\
(n=15)\end{array}$ & $\begin{array}{l}\text { Obe- } \\
\text { sity } \\
(n= \\
12)\end{array}$ & $\begin{array}{l}\text { Under- } \\
\text { weight } \\
\text { patients } \\
(n=10)\end{array}$ \\
\hline $\begin{array}{l}\text { Number } \\
\text { of women } \\
(\%)\end{array}$ & $16(80)$ & $12(80)$ & $\begin{array}{l}10 \\
(83)\end{array}$ & $8(80)$ \\
\hline $\begin{array}{l}\text { Number } \\
\text { of men }(\%)\end{array}$ & $4(20)$ & $3(20)$ & $2(17)$ & $2(20)$ \\
\hline Age, years & $\begin{array}{c}52.0 \\
(50.0- \\
60.0) \\
\end{array}$ & $\begin{array}{c}53.0 \\
(51.0- \\
62.0)\end{array}$ & $\begin{array}{c}52.0 \\
(50.0- \\
57.0)\end{array}$ & $\begin{array}{c}55.0 \\
(51.0- \\
59.0)\end{array}$ \\
\hline $\begin{array}{l}\text { Current } \\
\text { smoking, } \\
\text { n }(\%)\end{array}$ & 15 & 15.4 & 15.4 & 16.7 \\
\hline $\begin{array}{l}\text { RA dura- } \\
\text { tion, years }\end{array}$ & - & $\begin{array}{c}6.5 \\
(4.5-9) \\
\end{array}$ & $\begin{array}{c}6.0 \\
(5-9)\end{array}$ & $\begin{array}{c}6.7 \\
(5.4-10) \\
\end{array}$ \\
\hline $\begin{array}{l}\text { Rheuma- } \\
\text { toid factor } \\
\text { positivity, } \\
\text { n (\%) } \\
\end{array}$ & - & $13(87)$ & $\begin{array}{l}11 \\
(92)\end{array}$ & $9(90)$ \\
\hline $\begin{array}{l}\text { ACCP-posi- } \\
\text { tivity, } \\
\text { n (\%) }\end{array}$ & - & $14(93)$ & $\begin{array}{c}11 \\
(92)\end{array}$ & $9(90)$ \\
\hline $\begin{array}{l}\text { C-reactive } \\
\text { protein, } \\
\mathrm{Mг/л}\end{array}$ & - & $\begin{array}{c}20.5 \\
(14.9- \\
20.2) \\
\end{array}$ & $\begin{array}{l}20.0 \\
(14.0- \\
28.0) \\
\end{array}$ & $\begin{array}{c}22.0 \\
(13.0- \\
29.0)\end{array}$ \\
\hline $\mathrm{ESR}, \mathrm{mm} / \mathrm{h}$ & $\begin{array}{c}8.0 \\
(2.0- \\
10.0)\end{array}$ & $\begin{array}{c}35.5 \\
(26.0- \\
39.5)\end{array}$ & $\begin{array}{l}33.0 \\
(14.0- \\
38.0)\end{array}$ & $\begin{array}{c}31.0 \\
(15.0- \\
34.0)\end{array}$ \\
\hline DAS28 & - & $\begin{array}{c}7.3 \\
(6.3-7.8) \\
\end{array}$ & $\begin{array}{l}7.2 \\
(6.9- \\
7.7)\end{array}$ & $\begin{array}{c}7.4 \\
(6.2-8.1)\end{array}$ \\
\hline $\begin{array}{l}\text { Current } \\
\text { methotrex- } \\
\text { ate, } \\
n(\%)\end{array}$ & - & $11(73)$ & $\begin{array}{c}10 \\
(83)\end{array}$ & $8(80)$ \\
\hline $\begin{array}{l}\text { Current } \\
\text { prednisone } \\
\text { (low dos- } \\
\text { es), n (\%) }\end{array}$ & - & $6(40)$ & $5(42)$ & $4(40)$ \\
\hline $\begin{array}{l}\text { Current } \\
\text { NSAIDs, } \\
\mathrm{n}(\%)\end{array}$ & - & $5(33)$ & $3(25)$ & $3(30)$ \\
\hline
\end{tabular}

Data presented as median and quartiles to in percent's.

We assessed the disease activity with the Disease Activity Score (DAS28), including tender and swollen joint count and general health status. After overnight fasting, hemogram and leukocyte count, erythrocyte sedimentation rate (ESR), elemental serum biochemistry (electroIytes, urea, creatinine, albumin, standard liver function tests, transaminases, bilirubin, albumin), rheumatoid factor, and C-reactive protein (CRP) were determined. Blood samples were collected in sterile Vacutainer tubes, centrifuged at $3500 \mathrm{rpm}$ for 15 minutes at $4{ }^{\circ} \mathrm{C}$, and stored at $-80^{\circ} \mathrm{C}$ in pyrogen-free polyethylene tubes. Body mass index (BMI) was calculated according to the formula: [body weight/height $\left.{ }^{2}\right]\left(\mathrm{kg} / \mathrm{m}^{2}\right)$. 
We measured the serum concentration of adiponectin, VEGF, IL-6, cortisol using the BioVendor (Modrice, Czech Republic), Invitrogen (Camarillo, CA, USA), and Protein Contour Ltd (Saint-Petersburg, Russian Federation) kits with using immune-enzyme analysis (analyzer Statfax 2100, Awareness Technology Inc., USA). All data were processed using Statistica 6.0. (Statsoft, USA). Considering the asymmetrical shape of distribution (Kolmogorov-Smirnov test), data was presented as medians and ranges. Differences between unpaired samples were measured with the nonparametric Mann-Whitney test. We also performed a correlation analysis between all parameters studied in patients with RA.

Results and Discussion. In all patients enrolled in the study we find high levels of traditional markers of RA activity (DAS 28, ESR, CRP). We also registered high serum levels of proinflammatory cytokines, which are important in the pathogenesis of RA - TNF- $\alpha$, IL- 6 and anti-inflammatory interleukin-10 (IL-10) in all patients (Table 2).

Traditional markers of rheumatoid arthritis and several cytokine endocrine, endothelial biomarkers in different metabolic variants in patients treated with methotrexate and infliximab

\begin{tabular}{|c|c|c|c|c|c|}
\hline $\begin{array}{l}\text { Para- } \\
\text { meter }\end{array}$ & $\begin{array}{l}\text { Con- } \\
\text { trols } \\
(n=20)\end{array}$ & $\begin{array}{c}\text { We- } \\
\text { ek }\end{array}$ & $\begin{array}{c}\text { Normal } \\
\text { BMI } \\
(n=15)\end{array}$ & $\begin{array}{l}\text { Obesity } \\
(n=12)\end{array}$ & $\begin{array}{l}\text { Underweight } \\
\text { patients } \\
(\mathrm{n}=10)\end{array}$ \\
\hline \multirow[t]{2}{*}{ DAS28 } & & 0 & $7.3(6.3-7.8)^{*}$ & $7.2(6.9-7$. & $7.4(6.2-8.1)^{*}$ \\
\hline & & 2 & $p=$ & & $p=$ \\
\hline \multirow{2}{*}{$\begin{array}{l}\text { ESR } \\
\mathrm{mm} / \mathrm{h}\end{array}$} & \multirow{2}{*}{\begin{tabular}{l|}
12.3 \\
$(8.2-$ \\
$16.1)$
\end{tabular}} & 0 & $3.5(26$. & $39.3(24$ & $37.2(29.2-40.1)^{*}$ \\
\hline & & 22 & $\begin{aligned} & 21.0(17 \\
& p=c\end{aligned}$ & $26.1(1$ & $27.2(15$ \\
\hline \multirow{2}{*}{$\begin{array}{l}\text { CRP, } \\
\mathrm{mg} / \mathrm{I}\end{array}$} & \multirow{2}{*}{$\begin{array}{c}4.2 \\
(2.5- \\
6.1)\end{array}$} & 0 & $27.1(15.3-28.6)^{*}$ & $26.9(14$ & $25.2(13-29)^{*}$ \\
\hline & & 2 & $15.2 \underset{p=}{(10}$ & $\begin{array}{r}18.2(1 \\
p=\end{array}$ & $13.9(10$ \\
\hline \multirow[t]{2}{*}{$\begin{array}{l}\text { TNF- } \alpha, \\
\mathrm{pg} / \mathrm{ml}\end{array}$} & \multirow{2}{*}{$\begin{array}{l}15.2 \\
(6.3- \\
21.7)\end{array}$} & 0 & $163.2(98$ & $192.1(1$ & 17621 \\
\hline & & 22 & $\begin{array}{r}75.2(3 \\
p=\end{array}$ & $\begin{array}{r}82.1(6 \\
p=\end{array}$ & $\begin{array}{r}92.3(72 \\
p=\end{array}$ \\
\hline \multirow{2}{*}{$\begin{array}{l}\text { IL-6, } \\
\mathrm{pg} / \mathrm{ml}\end{array}$} & \multirow{2}{*}{$\begin{array}{l}10.2 \\
(4.7 \\
20.9\end{array}$} & & & 79)*§ & $209(167$ \\
\hline & & 22 & $\begin{array}{r}164.2(92 \\
p=(\end{array}$ & $\begin{array}{r}297.4(1 \\
p=\end{array}$ & $\begin{array}{r}143.4(12 \\
p=\end{array}$ \\
\hline \multirow{2}{*}{$\begin{array}{l}\text { IL-10, } \\
\mathrm{pg} / \mathrm{ml}\end{array}$} & \multirow{2}{*}{\begin{tabular}{|c|}
63.8 \\
$(29.1-$ \\
$79.05)$
\end{tabular}} & 0 & $373.7(283$ & $221.1(132$ & $419.2(382.1-534)^{*}$ \\
\hline & & 22 & $\begin{array}{r}361.2(293 \\
p=\end{array}$ & $\begin{array}{r}339.2(2 \\
p=\end{array}$ & $\begin{array}{c}310(29 \\
p=\end{array}$ \\
\hline \multirow{2}{*}{$\begin{array}{l}\text { Cor- } \\
\text { tisol } \\
\text { nmol/I }\end{array}$} & \multirow{2}{*}{\begin{tabular}{|c|}
378 \\
$(150-$ \\
$660)$
\end{tabular}} & 0 & $209(167.3-221)^{*}$ & $572.1(398.2-601) * \S$ & $301.2(298-352.1)^{*}$ \\
\hline & & 22 & $\begin{array}{r}287.2(201 \\
p=0\end{array}$ & $498(371$ & $\begin{array}{c}325.6(301.3-389.2)^{*} \\
p=0.06\end{array}$ \\
\hline \multirow{2}{*}{$\begin{array}{l}\text { Adipo- } \\
\text { nectin, } \\
\text { ng/mI }\end{array}$} & \multirow[t]{2}{*}{\begin{tabular}{|c|}
6.8 \\
$(3-7.1)$
\end{tabular}} & 0 & 890 & 211 & $12.7(\mathrm{~S}$ \\
\hline & & 2 & $\begin{array}{c}7.2(6 \\
p=\end{array}$ & $\begin{array}{r}5.8 \\
p\end{array}$ & $\begin{array}{r}9.1(8 \\
p=\end{array}$ \\
\hline \multirow{2}{*}{$\begin{array}{l}\text { VEGF, } \\
\mathrm{pg} / \mathrm{ml}\end{array}$} & \multirow{2}{*}{\begin{tabular}{|c|}
20 \\
$(12.3-$ \\
$39.4)$
\end{tabular}} & 0 & $111(73.1-158)^{*}$ & $175(171.8-203.9) * \S$ & $119(108.1-169.2)^{*}$ \\
\hline & & 22 & $\begin{array}{r}91(82-101 . \\
p=0.02\end{array}$ & $\begin{array}{r}92.7(81.9-11 \\
p=0.04\end{array}$ & $\begin{array}{c}95.2(76.3-105.1 \\
p=0.04\end{array}$ \\
\hline
\end{tabular}

Dynamics of indicators against the background of the use of infliximab is indicated in table as:

0 week - before the administration of infliximab, 22 weeks (after the fifth administration of infliximab).

Data are presented as: median and quartiles. Statistical differences in the treatment of each group were evaluated using the Wilcoxon test (pvalues are presented in the table) * - statistically significant differences with the control group (Mann-Whitney test), $\S$ - statistically significant difference with the group with normal body mass index (Mann-Whitney test).
Increasing VEGF serum production determined in patients with all metabolic variants. Serum adiponectin was detected t a higher level in the group with normal BMI compared to $\mathrm{ml}$. Proinflammatory cytokine activation was most intensive in nts who have had higher values of the concentraTNF- $\alpha$, IL- 6 and lower - IL-10 compared with patients 政 determined higher than the control group baseline cortisol whereas the group with normal BMI and hypotrophy, corticoncentration was reduced.

quacy of anti-inflammatory effect of the drug, which is manifested by a decreasing in the traditional indicators of RA activity (DAS28, ESR and CRP) and a decreasing TNF- $\alpha$, IL-6 of patients with obesity we determined reducing the concentration of IL-6, while in the groups with normal BMI and hypotrophy we registered reducing the concentration of this cytokine.

Table 2

Reduced adiponectin level significantly increased only in patients with obesity from $2.1(0.8-3.9) \mathrm{ng} / \mathrm{ml}$ to $5.8(4.9-$ 7.7) $\mathrm{ng} / \mathrm{ml}$. VEGF production after infliximab course significantly decreased in all groups, except for patients with a BMI reduction.

Serum cortisol level after infliximab therapy was significantly increased only in the group with normal BMI - from 209 (167.3-221) to 287.2(201.9-512.1) nmol/l $(p=0,04)$, in the group with obesity cortisol level was determined above the control values and did not change after treatment.

In patients with RA and different variants of methabolic status we found high activity of relevant biomarkers cytokine (TNF- $\alpha, \mathrm{IL}-6)$, and markers of endothelial dysfunction (VEGF). Thus in patients with obesity we registered maximum of proinflammatory activation, decreased adiponectin hypercorticoidism and moderately in comparison with the same parameters in patients with a normal body mass index. Infliximab demonstrated anti-inflammatory effect with decreasing of both the traditional indicators of RA activity (DAS28, ESR and CRP) and also decreasing of TNF- $\alpha$ production. Response to infliximab in patients with different variants of methabolic status homogeneous - optimal response registered in patients with normal and low body mass index, in patients with obesity we found persistently high levels of IL- 6 and cortisol.

Conclusions. Thus, we have found that in general, infliximab therapy may be quite effective in any variants of metabolic status with decreasing in both traditional markers of RA activity and the majority of the investigated immune, endocrine and endothelial biomarkers. In our opinion intensive proinflammatory activation and hypoadiponectinemia may decrease the effectiveness of the biologic therapy in RA patients. Given the growing obesity rate in RA we consider it necessary to develop recommendations for the normalization of body weight in the target group that can potentially increase the effectiveness of the expensive biologic therapy. 
References

1. Arnett F. C., Edworthy S. M., Bloch D. A., McShane D. J., Fries J. F. et al. The American Rheumatism Association 1987 revised criteria for the classification of rheumatoid arthritis. Arthritis Rheum. 1988;31:315324. doi: 10.1002/art.1780310302

2. Aletaha D., Neogi T., Silman A. J., Funovits J., Felson D. T. et al. 2010 Rheumatoid arthritis classification criteria: an American College of Rheumatology/ European League Against Rheumatism collaborative initiative. Arthritis Rheum. 2010;62:2569-2581. doi:10.1002/art.27584

3. Balabanova R. M., Erdes S. F. Rasprostranennost' revmaticheskih zabolevanij v Rossii v 2013-2014 gg. Nauchnoprakticheskaja revmatologija. 2014;53(2):120-124.

4. Ehling A., Schäffler A., Herfarth H., Tarner I. H., Anders S. et al. The potential of adiponectin in driving arthritis. J. Immunol. 2006; 176(7):4468-4478.

5. Gómez-Vaquero C., Nolla J. M., Fiter J., Ramon J. M., Concustell R. et al. Nutritional status in patients with rheumatoid arthritis. Joint Bone Spine. 2001:68(5):403-409.

6. Gremese E., Carletto A., Padovan M., Atzeni F., Raffeiner B. et al. Gruppo Italiano di Studio sulle Early Arthritis (GISEA). Obesity and reduction of the response rate to anti-tumor necrosis factor $\alpha$ in rheumatoid arthritis: an approach to a personalized medicine. Arthritis Care Res (Hoboken). 2013;65(1):94-100. doi: 10.1002/acr.21768

7. Hodkinson B., Tikly M., Adebajo A. Rheumatoid arthritis in the developing world: stepping up to the challenge. Clin Rheumatol. 2014;33(9):1195-1196. doi: 10.1007/s10067-014-2690-3

8. Imrich R., Vlcek M., Aldag J. C., Kerlik J., Radikova $Z$. et al. An endocrinologist's view on relative adrenocortical insufficiency in rheumatoid arthritis. Ann N Y Acad Sci. 2010;1193:134-138. doi: 10.1111/j.17496632.2009.05362.x
9. Laurberg T. B., Frystyk J., Ellingsen T., Hansen I. T., Jørgensen A. et al. Plasma adiponectin in patients with active, early, and chronic rheumatoid arthritis who are steroid- and disease-modifying antirheumatic drugnaïve compared with patients with osteoarthritis and controls. J. Rheumatol. 2009;36(9):1885-1891. doi: 10.3899/jrheum.080907

10. Lee Y. A., Ji H. I., Lee S. H., Hong S. J., Yang H. I. et al. The role of adiponectin in the production of IL-6, IL-8, VEGF and MMPs in human endothelial cells and osteoblasts: implications for arthritic joints. Exp. Mol. Med. 2014;46:e72. doi: 10.1038/emm.2013.141

11. Otero M., Lago R., Gomez R., Lago F., Dieguez C. et al. Changes in plasma levels of fat-derived hormones adiponectin, leptin, resistin and visfatin in patients with rheumatoid arthritis. Ann. Rheum. Dis. 2006;65(9):1198-1201

12. Szekanecz Z, Kerekes G., Dér H. Sándor Z Szabó Z. et al. Accelerated atherosclerosis in rheumatoid arthritis. Ann N Y Acad Sci. 2007;1108:349-358.

13. Wang Y., Wang X., Lau W. B., Yuan Y., Booth D. et al. Adiponectin inhibits tumor necrosis factor- $\alpha$-induced vascular inflammatory response via caveolin-mediated ceramidase recruitment and activation. Circ Res. 2014;114(5):792-805. doi: 10.1161/CIRCRESAHA. 114.302439

14. Weyer C., Funahashi T., Tanaka S., Hotta K., Matsuzawa Y. et al. Hypoadiponectinemia in obesity and type 2 diabetes: close association with insulin resistance and hyperinsulinemia. J. Clin. Endocrinol. Metab. 2001:86(5):1930-1935.

15. World Health Organization Report. Obesity: preventing and managing the global epidemic. WHO Obesity Technical Report Series 894. - World Health Organization: Geneva (Switzerland). 2004. http:// www.who.int/nutrition/publications/obesity/WHO_ TRS_894/en/.

About authors:

Oranskiy Sergey, MD; Associate Professor, Department of Faculty Therapy; tel.: +79183671067; e-mail: s_oransky@inbox.ru

Yeliseyeva Lyudmila, MD, PhD; Head of Faculty Therapy Division; e-mail: yeliseyeva@mail.ru

(C) Group of authors, 2016

UDC 616.379-008:616-056.52:612.017.12

DOI - http://dx.doi.org/10.14300/mnnc.2016.11020

ISSN $-2073-8137$

\title{
ASSOCIATION OF INSULIN RESISTANCE AND OBESITY WITH IMPAIRED IMMUNE RESPONSE TO HEPATITIS B VACCINATION IN HEALTH CARE WORKERS
}

\author{
Tkachenko L. I. ${ }^{1}$, Maleyev V. V. ${ }^{2}$, Rtishcheva L. V. ${ }^{1}$ \\ 1 Stavropol State Medical University, Russian Federation \\ 2 Central Research Institute of Epidemiology, Moscow, Russian Federation

\section{АССОЦИАЦИЯ ИНСУАИНОРЕЗИСТЕНТНОСТИ И ОЖИРЕНИЯ С НЕЭФФЕКТИВНОСТЬЮ ВАКЦИНАЦИИ ОТ ВИРУСНОГО ГЕПАТИТА В У МЕАИЦИНСКИХ РАБОТНИКОВ}

\author{
А. И. Ткаченко', В. В. Малеев ${ }^{2}$, Ртищева А. В. ${ }^{1}$ \\ 1 Ставропольский госуАарственный меАицинский университет, Российская ФеАерация \\ 2 Центральный научно-исслеАоватеАьский институт эпиАемиологии, \\ Москва, Российская ФеАерация
}

At the study was to evaluate immune response to HBV vaccine in Health care workers (HCWs) and detect risk factors of non-responsible persons. Descriptive retrospective analyses of antibodies' titer dynamics in 98 HBV vaccinated HCWs conducted from 1998 to 2011 years annually were evaluated by measuring serum HBsAb levels, by ob- 